\title{
Achievement of Paris climate goals unlikely due to time lags in the land system
}

Calum Brown*1, Peter Alexander ${ }^{2,3}$, Almut Arneth ${ }^{1}$, Ian Holman ${ }^{4}$, Mark Rounsevell ${ }^{1,2}$

${ }^{1}$ Institute of Meteorology and Climate Research, Atmospheric Environmental Research (IMK-IFU), Karlsruhe Institute of Technology, Kreuzeckbahnstraße 19, 82467 Garmisch-Partenkirchen, Germany

${ }^{2}$ School of Geosciences, University of Edinburgh, Edinburgh EH8 9XP, UK

${ }^{3}$ Global Academy of Agriculture and Food Security, The Royal (Dick) School of Veterinary Studies, Easter Bush Campus, Midlothian, EH25 9RG, UK

${ }^{4}$ Cranfield Water Science Institute, Cranfield University, Bedford MK43 OAL, UK

Achieving the Paris Agreement's aim of limiting average global temperature increases to $1.5^{\circ} \mathrm{C}$ requires substantial changes in the land system. However, individual countries' plans to accomplish these changes remain vague, almost certainly insufficient and unlikely to be implemented in full. These shortcomings are partially the result of avoidable 'blind spots' relating to time lags inherent in the implementation of landbased mitigation strategies. Key blind spots include inconsistencies between different land system policies, spatial and temporal lags in land system change, and detrimental consequences of some mitigation options. We suggest that improved recognition of these processes is necessary to identify achievable mitigation actions, avoiding excessively optimistic assumptions and consequent policy failures. 
Human land use contributes approximately one quarter of anthropogenic emissions and severely constrains the expansion of terrestrial carbon sinks ${ }^{1,2}$. Limiting average global temperature increases to between $1.5^{\circ} \mathrm{C}$ and $2^{\circ} \mathrm{C}$, as agreed in 2015 by the 195 signatories to the UN Framework Convention on Climate Change 'Paris Agreement ${ }^{3}{ }^{3}$, will therefore require substantial interventions in the land system in the absence of dramatic reductions in fossil fuel emissions ${ }^{2,4}$. Planned interventions include the prevention of further deforestation, reforestation (or afforestation) over millions of hectares, reduction of agricultural greenhouse gas emissions, and widespread adoption of bioenergy with carbon capture and storage. These are crucial components of many of the (Intended) Nationally Determined Contributions (NDCs) by which countries propose to implement the Paris Agreement (e.g. ${ }^{5-7}$ ), and also of the projected negative emissions pathways that must complement them ${ }^{8,9}$.

These - and additional - mitigation actions must now be implemented very rapidly if the Paris goal is to be achieved ${ }^{10,11}$. However, proper assessment of mitigation options and NDCs requires factoring in the speed with which ambition and policy translate into beneficial on-the-ground activity. Without this, unrealistic expectations about the rate and extent of mitigation will delay and eventually preclude the adoption of appropriate targets ${ }^{12,13}$. This effect is already clear in land-based mitigation policies, which are affected by a number of time lags that are rarely anticipated in the design of mitigation policies ${ }^{14}$. Partly as a result, of the 197 countries that have produced NDCs to date (representing $96.4 \%$ of global greenhouse gas emissions) ${ }^{15}$, no major industrialised country has yet matched its own ambitions for emissions reductions ${ }^{10}$. Of 32 countries (representing $80 \%$ of anthropogenic emissions) considered by the independent scientific organisation Climate Action Tracker, only two (Morocco and the Gambia) are rated as achieving 'Paris Agreement compatible' implementation of their $\mathrm{NDCs}^{16}$. Global $\mathrm{CO}_{2}$ emissions appear to have risen in both 2017 and 2018 after previously levelling off ${ }^{1}$. We argue that such setbacks can and must be avoided by improved assessment and recognition of the time lags inherent in land system policy-making, management change, and feedback dynamics. 


\section{Intended actions}

NDCs set out a number of relatively consistent approaches to reaching the aim of the Paris Agreement. Among these, changes in the use, management and cover of land are particularly significant, with land system sinks by 2030 expected to account for at least an additional $3.7 \mathrm{GtCO}_{2} \mathrm{e} / \mathrm{y}$ above 2005 levels (or 20 $25 \%$ of the emissions from all sectors) ${ }^{17,18}$. Of the more than 175 countries that had produced an NDC by November 2015, nearly 100 explicitly identified mitigation strategies involving land use ${ }^{17}$. The most common single strategy is related to increasing forest carbon sinks by reducing deforestation rates or increasing reforestation rates. The NDCs of India, Indonesia, Russia, China and, especially, Brazil, all emphasise this strategy, with Brazil and Indonesia planning to reduce land system emissions more than any other countries 4,6,7,18,19. In Brazil, a 70\% reduction in deforestation rates between 2005 and 2013 (from an average of 19,500 $\mathrm{km}^{2} / \mathrm{y}$ to $5,843 \mathrm{~km}^{2} / \mathrm{y}$ ) prompted plans for further forest-based emissions savings accounting for nearly half of the global total ${ }^{17,20}$. China plans to increase forest stocks by 40 million hectares between 2009 and $2020{ }^{5}$. Agriculture is also expected to make a crucial contribution through, for instance, reductions in emissions associated with pesticide and fertiliser production and usage, pasture land restoration, agro-forestry initiatives, utilisation of agricultural waste products, water and soil conservation, and adoption of new crops (e.g. ${ }^{5,7}$ ). Widespread bioenergy generation (with carbon capture and storage) is also fundamental to most projected pathways for achieving the Paris Agreement ${ }^{9}$.

\section{Unrealistic NDC objectives}

Many of the proposals contained in NDCs fall short of the 'transformative' change required by the Paris Agreement, as they represent or incorporate a continuation of established trends in national land systems ${ }^{10}$. Furthermore, these trends are subject to a range of contingencies that are likely to reduce or negate even 
this insufficient contribution, and which make planned mitigation dependent on consistently high levels of political will and capacity. One important example is the increase in deforestation that has occurred since the Paris Agreement, immediately undermining the assumption enshrined in several NDCs that deforestation rates would continue to slow as they had in the preceding years. For instance, deforestation increased by 29\% between 2015 and 2016 in Brazil and by $44 \%$ in Colombia ${ }^{21,22}$. These increases probably occurred in response to higher demand for meat, failure to protect forest areas and indigenous peoples' land rights, and even the demobilisation of the FARC rebel group, which had previously controlled logging across large areas in Colombia ${ }^{20,22,23}$. Altogether, global emissions from deforestation and land use change appear to have remained stable since $2007^{1}$. Such setbacks can have fundamental implications for efforts to curb climate change: derailing ambitious targets, sapping motivation and engendering cynicism. However, experience shows that they are both more common and more predictable than they appear, often stemming from basic processes in three main areas: policy development, practical adoption, and indirect, unanticipated effects on other processes or areas.

\section{Policy development}

The voluntary nature of the Paris Agreement means that NDCs are not required to be demonstrably achievable, and in most cases have no defined plan of implementation even where sufficient political will and capacity exists ${ }^{18,24}$. For instance, EU Member States' binding targets for up to $40 \%$ reductions in GHG emissions by 2030 rely on net-zero emissions from land-based sectors, but leave very little time for designing and implementing appropriate land management strategies ${ }^{25,26}$. These steps will be further complicated by ongoing scientific uncertainty about exactly how, and how much, land system mitigation can be achieved ${ }^{18}$. Establishing the new, more ambitious policies that will need to be implemented in the second half of this century is likely to prove more challenging still ${ }^{12,27}$. 
NDCs are therefore highly vulnerable to the complex, short-term and cyclical nature of the policy-making process. This process involves the repeated assessment of problems, opportunities and potential interventions, all of which are subject to conflicts between different interests, before final implementation can occur (Fig. 1). Time lags exist at every stage of this process and can lead to lengthy delays, mistakes and reversals, affecting every facet of the NDCs within and beyond the land system. Indeed, perhaps the greatest single threat to achievement of the $1.5^{\circ}$ goal (aside from the long delay in adopting such a goal) is the likelihood, if not inevitability, of changes in policy objectives. The United States Government's planned withdrawal from the Paris Agreement is one such example ${ }^{28}$, as is the rapid increase in land clearing in Queensland, Australia, the rate of which rivalled that in Brazil following the rejection of stronger regulations by the Queensland Parliament ${ }^{29}$.

Such changes often result from legitimate democratic processes, driven by concerns about the loss of livelihoods, traditions and cultures, as well as perceived links between climate science, globalisation, and a lack of democratic accountability ${ }^{30}$. Socio-economic inequalities within and between countries also create inevitable opposition to mitigation policies that are perceived as disproportionately penalising those who are most vulnerable and least responsible for global emissions ${ }^{31}$. Strategies based on public participation, such as those that seek to empower indigenous peoples while presuming certain uses of their lands such as conservation or reforestation, are particularly at risk of failure ${ }^{7,32}$.

Equally capable of undermining mitigation policies is conflict between objectives or sections of government, which occurs at every stage of the policy cycle. This frequently subordinates climate policy to other sectoral and political considerations, resulting either in a failure to legislate at all (e.g. the Australian Government's recent abandonment of emissions targets for the energy sector in line with the Paris Agreement ${ }^{33}$ ), or contradictory objectives that undermine genuine mitigation (e.g. the Scottish Government's development of 'world-leading' climate policies and simultaneous financial support for fossil fuel extraction ${ }^{34,35}$ ). Problems of this kind are exacerbated by the multi-functional nature of the land system and consequent trade-offs 
between mitigation and other land-based objectives. A stark example is provided by Oil Palm cultivation in countries such as Indonesia and, increasingly, Peru, which leads to substantial emissions from deforestation and peatland degradation ${ }^{36}$. Indonesia's Forest Moratorium policy (designed to reverse the state-supported spread of Oil Palm plantations) has had limited or even counterproductive effects because of its incompatibility with existing policies and economic drivers, often producing only temporary slowing of deforestation in some areas and commensurate increases elsewhere ${ }^{36,37}$. Similarly, the decision by the Democratic Republic of the Congo to allow logging and forest resource extraction to recommence after a moratorium initiated in 2002 has contributed to continuing rapid deforestation ${ }^{38}$. The rates of primary forest loss in the Congo and Indonesia are now 1.5 and 3 times the rate in Brazil, and continue to include widespread clearance of peatland ${ }^{39}$.

Such contradictions between policies are particularly hard to resolve where a lack of institutional capacity exists, posing major challenges for countries with poorly functioning governance and judicial systems as they attempt to reduce illegal logging ${ }^{20,40}$. Similarly, nominal protections have been ineffectual in changing the behaviours of companies and communities involved in forest clearance in Indonesia ${ }^{41}$, or in controlling deforestation in the Congo caused by smallholder agriculturalists escaping conflict zones ${ }^{39}$. Russia's ambitious plans for forest-based mitigation are also likely to be hamstrung by the fragmented, contradictory and ineffective nature of forest policies at different governance levels ${ }^{42,43}$. Even where domestic political capacity is high, the scope for legislation may be limited by international trading agreements that allow economic interests to delay or override national policy objectives (e.g. through state-investor dispute settlement systems) ${ }^{44,45}$.

\section{Adoption}

Even when implemented, mitigation policies suffer from further time lags as on-the-ground uptake occurs

(Fig. 2). Many NDC actions depend on the willingness of people to adopt innovations in technology, crops or 
management approaches, particularly in the case of voluntary actions that play a substantial role in the NDCs of the USA, China and India, amongst others. For example, the United States Department of Agriculture expects voluntary changes in agriculture and forestry to reduce net emissions by $0.12 \mathrm{GtCO}_{2} \mathrm{e} / \mathrm{y}$ in $2025^{17}$, while China and India encourage reforestation through voluntary tree planting by all citizens ${ }^{5,46}$. Such voluntary measures are likely to have less impact than those supported by regulations or subsidies, although they may play an important role in ensuring that local communities can engage meaningfully with mitigation efforts ${ }^{20,47}$. Even where mitigation policies are supported by subsidies or regulations, however, uptake (or compliance) is generally a gradual, spatially-structured process that depends upon knowledge, socio-cultural context, personal experience and the presence of charismatic leaders or 'champions' who can initiate widespread action ${ }^{47,48}$.

There are already many examples of mitigation policies that have initially failed to deliver their expected benefits because of delays in uptake. The Brazilian Low Carbon Agriculture programme produced only 5 approved projects in its first year (2010), though uptake has since been rising and now exceeds 25,000 farms, approximately $0.5 \%$ of the Brazilian total ${ }^{49}$. The 2012 Brazilian Forest Code has also had unexpectedly low uptake and compliance, perhaps due to inadequate financial incentives ${ }^{50}$. It is anticipated that only around a third of the global mitigation potential in agriculture will be achieved by 2030 , with major barriers existing in the developing world, where clear benefit to farmers must be demonstrated if uptake is to occur 51.

Uptake is likely to take even longer where it depends on a wider range of contingencies, for example where it spans polities or societies, generally only reaching saturation over decades rather than years as social, political, technological and economic forces interact (Fig. 2) ${ }^{52,53}$. This is apparent in the recent development of agricultural 'micro-insurance' as a risk mitigation response to projected weather extremes. Initial uptake of this insurance has been very slow and spatially patchy, with uptake across Africa, for example, gradually increasing from 2005 onwards to cover $0.2 \%$ of the population in 2011 and $1.1 \%$ in $2014{ }^{54,55}$. Similar 
dynamics are at play in the global spread of Conservation Agriculture (Fig. 2), as practices to preserve soils and diversify crops are gradually recognised, promoted and adopted in different countries ${ }^{56}$. The timescales involved contrast sharply with those over which political decisions are made, increasing the likelihood of policies being abandoned or reversed before they have had time to take effect. Significantly for the Paris Agreement, delays in uptake are greatest where the agricultural sector comprises many small farms, as in the case of India and, especially, China ${ }^{57}$.

\section{$\underline{\text { Indirect effects }}$}

Climate and land system policies are strongly cross-sectoral, with dependencies that span traditionally discrete areas of research and governance. This can generate another form of time lag via indirect and counterproductive consequences that delay the achievement of expected mitigation targets. For instance, many of the changes proposed in the agricultural sector in NDCs depend upon balancing the potential benefits of intensification (e.g. land sparing) and its potential drawbacks (e.g. enhanced energy inputs, erosion and decreasing water quality) that tend to fall under the purview of different Government departments. Failures to adequately anticipate trade-offs of this kind have been a notable feature of climate policy in the land system, with policies for different sectors and for mitigation and adaptation often being at

odds with one another ${ }^{58}$. In particular, mitigation policies focusing on bioenergy have often proved detrimental to food production, forest cover and, ultimately, the very mitigation targets to which bioenergy contributes ${ }^{59}$. Similarly, EU renewable energy targets have been criticised for causing the loss of established forests in Europe, and with them important carbon sinks and ecosystems ${ }^{60}$. International trade and telecoupling can make such unanticipated consequences more likely, as when successful regulation of illegal deforestation in one area increases timber prices and therefore legal deforestation in another area ${ }^{61}$, or as in the case of EU bioenergy production and imports contributing to tropical deforestation ${ }^{62}$. International policy has only dealt with such counter-productive 'leakage', whether from public policy or private (corporate) initiatives, to a very limited extent ${ }^{62,63}$. 
Counter-productivities can also result from excessive focus on particular outcomes. For example, failure to account for emissions of greenhouse gases (such as $\mathrm{N}_{2} \mathrm{O}$ ) from biofuel crop growth offsets their $\mathrm{CO}_{2}$ savings, while emissions of $\mathrm{O}_{3}$ precursor gases (such as $\mathrm{NO}_{x}$ or biogenic volatile organic compounds) in addition decreases crop yields (as well as negatively affecting biodiversity and human health) ${ }^{64,65}$. China's 'Grain for Green' programme has similarly shown success in meeting its targets as defined, but with some negative socio-economic and ecological consequences that may undermine its long-term sustainability ${ }^{66}$. Both of these examples may be symptomatic of the ways in which negative impacts of afforestation and bioenergy production on the provision of ecosystem services can lead to societal resistance or additional emissions, slowing the rate of effective mitigation ${ }^{67}$.

Failure to consider the cross-sectoral context of mitigation actions also risks double-counting their benefits. This is apparent in the reliance of several countries' NDCs on existing decreases in rates of deforestation, implying a fundamental lack of truly additional mitigation, as well as a potential impermanence. As with Indonesia's Forest Moratorium, any isolation of mitigation policy from economic drivers is likely to prove illusory, leading to leakage of destructive pressures to other areas ${ }^{37}$. These effects are particularly great where the real or effective price of carbon is low, allowing other economic drivers to remain dominant, and where free trade enhances teleconnections ${ }^{68}$.

\section{Ensuring achievability}

The various dependencies (and acknowledged insufficiencies) of the actions planned in support of the Paris Agreement mean that achievement of the $1.5^{\circ} \mathrm{C}$ (or even a $2^{\circ} \mathrm{C}$ ) goal is highly unlikely ${ }^{10,69}$. Given the urgent need for climate change mitigation, there are strong arguments to be made for international climate policy to rely on binding or regulatory commitments that either take a leading role in economic policies or 
supersede them entirely ${ }^{24,45,70,71}$. Trading arrangements that actively promote mitigation or formal 'peerreview' of proposed policies have both been suggested as proven options ${ }^{70,71}$. However, these approaches cannot in themselves ensure rapid on-the-ground change, especially given the risks of democratic backlash and limited responsiveness to both scientific and political developments ${ }^{30}$.

A crucial step towards achieving the required level of mitigation is therefore the prioritisation of behaviourally-literate policy making that better accounts for the dynamics of land system change ${ }^{72}$. These dynamics, as described above, do not simply represent complexities of the policy process, but linked and often logical responses to difficult, long-term challenges. As a result, the current failure to account for land system time lags in mitigation is not inevitable. Instead, it is possible - and essential - that these time lags are better anticipated, so that achievable pathways to limiting global temperature increases can be developed.

At a basic level, these pathways should ensure obvious and immediate benefits to farmers, smallholders and foresters who undertake mitigation actions, especially in developing countries where land management options are scarce ${ }^{37,51}$. Beyond such recognised solutions, existing evidence should be better exploited to identify promising strategies. Empirical studies of time lags in policy-driven land system change can illuminate political pathways to transformation ${ }^{73}$, as well as allowing the incorporation of more realistic dynamics in models that project future land system dynamics to support policy decisions. To date, such work has usually focused on case-specificities rather than synthesis ${ }^{74}$, leaving policy development to rely on an assumption of rapid or instantaneous adoption according to generic patterns ${ }^{14}$. Furthermore, the sectoral nature of most analyses means that they are not able to illuminate many of the indirect effects that can undermine mitigation outcomes ${ }^{74,75}$. These shortcomings can actively obscure the time lags identified here if the limitations of the knowledge base being used are not clear ${ }^{76}$. 
We suggest that a small number of specific developments in land system research, modelling and policy development have the potential to dramatically improve climate mitigation policies by allowing exploration of the key time lags in policy outcomes. These developments cannot, of course, be allowed to introduce time lags of their own, and so must complement an immediate recognition of the inherent delays in land system change.

Firstly, improved recognition, understanding and modelling of the policy-making process should be prioritised. This can be achieved through ongoing research into governance structures and mechanisms, including the effects of cross-scale interactions from national to state to regional levels ${ }^{77,78}$, and compilation of a wide range of relevant case studies including by expert elicitation and comparative analyses of political processes ${ }^{14,73,79}$. Meanwhile, the development of agent-based land use models towards representations of political decision-making can contribute by generating empirically-based projections that inform policydevelopment, replacing misleading assumptions ${ }^{80,81}$.

Secondly, there is a need for more research into processes and rates of uptake of land management approaches, allowing efficient targeting of policies as well as improvements to the 'one-size-fits-all' assumptions that currently dominate ${ }^{14,82}$. This is a necessary continuation of attempts to resolve top-down and bottom-up assessments of emissions reduction potentials ${ }^{83}$.

Thirdly, a substantial increase in the number and quality of analyses of indirect and cross-sectoral consequences of changes in the land system is required. These can build on existing economic assessments of trading relationships ${ }^{84}$, increasingly extensive knowledge of inter-sectoral and inter-locational impacts ${ }^{85}$, and recent attempts to model coherent, multi-sectoral land systems ${ }^{74,86,87}$. These may also help to identify promising new strategies such as the use of 'natural climate solutions' that use cost-effective land management changes to provide substantial mitigation alongside a range of other ecosystem service benefits ${ }^{88}$, or 'burden sharing' between distinct policy areas ${ }^{14}$. 
Finally, land system models should be embedded in appropriate uncertainty frameworks to identify robust, location-specific interventions ${ }^{86}$, partly through integration of knowledge derived from different modelling paradigms ${ }^{89,90}$.

These developments are significant but achievable, relying on existing and emerging research areas that have already established their utility. Of particular importance are ongoing moves towards integrative research that operates across scientific disciplines, case studies and models ${ }^{91,92}$, as these not only reveal 'blind spots' of the kind identified here, but also ways in which these can be accounted for. Such an approach is urgently required to identify implementable climate mitigation actions, and therefore to achieve the transformative changes envisioned by the parties to the Paris Agreement.

\section{Correspondence}

Correspondence and requests for materials should be sent to $C B$.

\section{Acknowledgements}

This research was supported by the Helmholtz Association, the UK's Global Food Security Programme project Resilience of the UK food system to Global Shocks (RUGS, BB/N020707/1), and the European Union's Seventh Framework Programme projects LUC4C (grant no. 603542) and IMPRESSIONS (grant no. 603416).

\section{Author Contributions}

$C B$ carried out data and literature reviews, and wrote the manuscript with assistance from $P A, A A, I H$ and MR. 


\section{References}

1. Le Quéré, C. et al. Global Carbon Budget 2018. Earth Syst. Sci. Data 10, 2141-2194 (2018).

2. IPCC. in Climate Change 2014: Mitigation of Climate Change. Contribution of Working Group III to the Fifth Assessment Report of the Intergovernmental Panel on Climate Change (eds. [Edenhofer, O., R., Pichs-Madruga, Y. Sokona, E. Farahani, S. Kadner, K. Seyboth, A. Adler, I. Baum, S. Brunner, P. Eickemeier, B. Kriemann, J. \& Savolainen, S. Schlömer, C. von Stechow, T. Z. and J. C. M.) 811-922 (Cambridge University Press, 2014). doi:10.1016/j.phrs.2011.03.002

3. United Nations Framework Convention on Climate Change. The Paris Agreement. The Paris Agreement (2016). Available at: http://unfccc.int/paris_agreement/items/9485.php. (Accessed: 18th July 2016)

4. Grassi, G. et al. The key role of forests in meeting climate targets requires science for credible mitigation. Nat. Clim. Chang. 7, 220-226 (2017). Establishes the importance of land-based mitigation and forests in particular to achievement of the Paris Agreement, as well as the associated difficulties.

5. National Development and Reform Commission of China. Enhanced Actions on Climate Change: China's intended nationally determined contributions. Unfccc 36 (2015). doi:http://www4.unfccc.int/submissions/INDC/Published\%20Documents/China/1/China's\%20INDC\% 20-\%20on\%2030\%20June\%202015.pdf

6. Union Environment Ministry. India's Intended Nationally Determined Contribution. Unfccc/Indc 1-38 (2015). doi:10.1017/СВ09781107415324.004

7. Federative Republic of Brazil. Intended Nationally Determined Contribution: Towards achieving the objective of the United Nations Framework Convention on Climate Change. 9, 6 (2015). 
8. Walsh, B. et al. Pathways for balancing CO2 emissions and sinks. Nat. Commun. 8, 14856 (2017).

9. Tokimatsu, K., Yasuoka, R. \& Nishio, M. Global zero emissions scenarios: The role of biomass energy with carbon capture and storage by forested land use. Appl. Energy 185, 1899-1906 (2017).

10. Victor, D. G. et al. Prove Paris was more than paper promises. Nature 548, 25-27 (2017).

11. Millar, R. J. et al. Emission budgets and pathways consistent with limiting warming to $1.5^{\circ} \mathrm{C}$. Nat. Geosci. (2017). doi:10.1038/ngeo3031

12. Peters, G. P. The'best available science'to inform 1.5 [deg] C policy choices. Nat. Clim. Chang. (2016).

13. Manoli, G., Katul, G. G. \& Marani, M. Delay-induced rebounds in CO2emissions and critical timescales to meet global warming targets. Earth's Futur. 4, 636-643 (2016).

14. Turner, P. A., Field, C. B., Lobell, D. B., Sanchez, D. L. \& Mach, K. J. Unprecedented rates of land-use transformation in modelled climate change mitigation pathways. Nat. Sustain. 1, 240-245 (2018). Explores the realism of assumptions about speed of land system change underlying mitigation projections and policies.

15. World Resources Institute. CAIT. Climate Data Explorer. Country GHG Emissions. CAIT 2.0 WRI'S Data Explorer (2018). Available at: http://cait.wri.org/indc/. (Accessed: 20th August 2018)

16. Climate Action Tracker. Countries | Climate Action Tracker. (2018). Available at: https://climateactiontracker.org/countries/. (Accessed: 20th August 2018)

17. Grassi, G. \& Dentener, F. Quantifying the contribution of the land use sector to the Paris climate agreement. Brussels Eur. Comm. doi (2015).

18. Forsell, N. et al. Assessing the INDCs' land use, land use change, and forest emission projections. Carbon Balance Manag. 11, 26 (2016). Provides a detailed overview of the planned contributions of the land system to countries' mitigation actions. 
19. Russian Federation. Federal Service For Hydrometeorology And Environmental Monitoring First Biennial Report Of The Russian Federation Moscow 2014. (2014).

20. Nepstad, D. et al. Slowing Amazon deforestation through public policy and interventions in beed and soy supply chains. Science (80-. ). 344, 1118-1123 (2014). Elucidates the factors contributing to slowing deforestation in Brazil, as well as their vulnerability to political, social and economic change.

21. World Resources Institute. Brazilian Government Announces 29 Percent Rise in Deforestation in 2016 | World Resources Institute. (2016). Available at: http://www.wri.org/blog/2016/12/braziliangovernment-announces-29-percent-rise-deforestation-2016. (Accessed: 10th July 2017)

22. Colombia Reports. Deforestation in Colombia up 44\% in 2016: report. (2017). Available at: https://colombiareports.com/colombias-deforestation-rate-44-2016report/?utm_content=buffer6c425\&utm_medium=social\&utm_source=twitter.com\&utm_campaign= buffer. (Accessed: 10th July 2017)

23. Reuters. Amazon protectors: Brazil's indigenous people struggle to stave off loggers | Reuters. (2017). Available at: http://www.reuters.com/article/us-brazil-landrights-indigenous-idUSKBN18X1MX. (Accessed: 10th July 2017)

24. Viñuales, J. E., Depledge, J., Reiner, D. M. \& Lees, E. Climate policy after the Paris 2015 climate conference. Clim. Policy 17, 1-8 (2017).

25. European Union. Intended Nationally Determined Contribution of the EU and its Member States. 1-7 (2015). doi:10.1613/jair.301

26. EU. Regulation (EU) 2018/841 of the European Parliament and of the Council of 30 May 2018 on the inclusion of greenhouse gas emissions and removals from land use, land use change and forestry in the 2030 climate and energy framework, and amending Regulation (. (https://eur- 
lex.europa.eu/legal-content/EN/TXT/?uri=uriserv:OJ.L_.2018.156.01.0001.01.ENG, 2018).

27. Rogelj, J. et al. Perspective : Paris Agreement climate proposals need boost to keep warming well below $2{ }^{\circ}$ C. Nat. Clim. Chang. 534, 631-639 (2016).

28. Sanderson, B. M. \& Knutti, R. Delays in US mitigation could rule out Paris targets. Nat. Clim. Chang. 7, 92-94 (2016).

29. Reside, A. E. et al. Ecological consequences of land clearing and policy reform in Queensland. Pacific Conserv. Biol. (2017). doi:10.1071/PC17001

30. Stehr, N. Exceptional Circumstances - Does Climate Change Trump Democracy? Issues Sci. Technol. 32, 37-44 (2016).

31. Chancel, L. \& Piketty, T. Carbon and Inequality from Kyoto to Paris: Trends in the global inequality of carbon emissions (1998-2013) and prospects for an equitable adaptation fund. Paris Sch. Econ. (2015).

32. Bäckstrand, K. \& Lövbrand, E. Planting Trees to Mitigate Climate Change: Contested Discourses of Ecological Modernization, Green Governmentality and Civic Environmentalism. Glob. Environ. Polit. 6, $50-75(2006)$.

33. Reuters. Australia waters down commitment to climate accord amid domestic political fight | Reuters. (2018). Available at: https://www.reuters.com/article/climatechange-accordaustralia/australia-waters-down-commitment-to-climate-accord-amid-domestic-political-fightidUSL3N1VB1VZ. (Accessed: 20th August 2018)

34. Scottish Government. Oil and gas innovation spend up. (2017). Available at: https://news.gov.scot/news/oil-and-gas-innovation-spend-up. (Accessed: 5th July 2017)

35. Scottish Government. Scotland's Action on Climate Change. (2017). Available at: 
http://www.gov.scot/Topics/Environment/climatechange. (Accessed: 5th July 2017)

36. Lilleskov, E. et al. Is Indonesian peatland loss a cautionary tale for Peru? A two-country comparison of the magnitude and causes of tropical peatland degradation. Mitigation and Adaptation Strategies for Global Change 1-33 (2018). doi:10.1007/s11027-018-9790-3

37. van Noordwijk, M., Agus, F., Dewi, S. \& Purnomo, H. Reducing emissions from land use in Indonesia: motivation, policy instruments and expected funding streams. Mitig. Adapt. Strateg. Glob. Chang. (2013). doi:10.1007/s11027-013-9502-y

38. Reuters. Congo approves logging near carbon-rich peatlands | Reuters. (2018). Available at: https://www.reuters.com/article/us-congo-environment/congo-approves-logging-near-carbon-richpeatlands-idUSKCN1G42LE. (Accessed: 4th September 2018)

39. Turubanova, S., Potapov, P. V, Tyukavina, A. \& Hansen, M. C. Ongoing primary forest loss in Brazil, Democratic Republic of the Congo, and Indonesia. Environ. Res. Lett. 13, 074028 (2018). Provides an up-to-date overview of rates and reasons for deforestation in countries with some of the largest planned land system emissions reductions.

40. Goncalves, M. P., Panjer, M., Greenberg, T. S. \& Magrath, W. B. Justice for Forests - Improving Criminal Justice Efforts to Combat Illegal Logging. World bank Study (2012). doi:10.1596/978-0-8213$8978-2$

41. Suwarno, A., van Noordwijk, M., Weikard, H.-P. \& Suyamto, D. Indonesia's forest conversion moratorium assessed with an agent-based model of Land-Use Change and Ecosystem Services (LUCES). Mitig. Adapt. Strateg. Glob. Chang. 23, 211-229 (2018).

42. Proskurina, S., Heinimö, J. \& Vakkilainen, E. Policy forum: Challenges of forest governance: Biomass export from Leningrad oblast, North-West of Russia. For. Policy Econ. 95, 13-17 (2018). 
43. Henry, L. A. \& Tysiachniouk, M. The uneven response to global environmental governance: Russia's contentious politics of forest certification. For. P 90, 97-105 (2018).

44. Green, A. Climate Change, Regulatory Policy and the WTO. J. Int. Econ. Law 8, 143-189 (2005).

45. Tienhaara, K. Regulatory Chill in a Warming World: The Threat to Climate Policy Posed by InvestorState Dispute Settlement. Transnatl. Environ. Law 7, 229-250 (2018).

46. Times of India. Madhya Pradesh ready for 'record' plantation today | Bhopal News - Times of India. (2017). Available at: http://timesofindia.indiatimes.com/city/bhopal/mp-ready-for-record-plantationtoday/articleshow/59405501.cms. (Accessed: 3rd July 2017)

47. Jewitt, S. Special Paper: Voluntary and 'Official' Forest Protection Committees in Bihar: Solutions to India's Deforestation? J. Biogeogr. 22, 1003 (1995).

48. Hamilton-Webb, A., Manning, L., Naylor, R. \& Conway, J. The relationship between risk experience and risk response: a study of farmers and climate change. J. Risk Res. 20, 1379-1393 (2017).

49. CGIAR. Home | Climate-Smart Agriculture Guide. (2017). Available at: https://csa.guide/. (Accessed: 6th July 2017)

50. Azevedo, A. A. et al. Limits of Brazil's Forest Code as a means to end illegal deforestation. Proc. Natl. Acad. Sci. U. S. A. 114, 7653-7658 (2017).

51. Scholes, R. J., Palm, C. A. \& Hickman, J. E. Agriculture and Climate Change Mitigation in the Developing World. CGIAR Res. Progr. Clim. Chang. Agric. Food Secur. (CCAFS). Working Pa, (2014).

52. Sousa, I. S. F. de \& Busch, L. Networks and Agricultural Development: The Case of Soybean Production and Consumption in Brazil. Rural Sciology 63, 349-371 (1998).

53. Jayne, T. S., Mather, D. \& Mghenyi, E. Principal Challenges Confronting Smallholder Agriculture in Sub-Saharan Africa. World Dev. 38, 1384-1398 (2010). 
54. The Microinsurance Centre. The Landscape of Microinsurance Africa 2015. (2016).

55. Fonta, W. M., Sanfo, S., Kedir, A. M. \& Thiam, D. R. Estimating farmers' willingness to pay for weather index-based crop insurance uptake in West Africa: Insight from a pilot initiative in Southwestern Burkina Faso. Agric. Food Econ. 6, 11 (2018).

56. Kassam, A., Friedrich, T., Derpsch, R. \& Kienzle, J. Overview of the Worldwide Spread of Conservation Agriculture. (2015).

57. Lowder, S. K., Skoet, J. \& Raney, T. The Number, Size, and Distribution of Farms, Smallholder Farms, and Family Farms Worldwide. World Dev. 87, 16-29 (2016).

58. Di Gregorio, M. et al. Climate policy integration in the land use sector: Mitigation, adaptation and sustainable development linkages. Environ. Sci. Policy 67, 35-43 (2017). Explores the policy contexts and conflicts that affect mitigation and adaptation, with a focus on Indonesia.

59. Searchinger, T. et al. Use of U.S. Croplands for Biofuels Increases Greenhouse Gases Through Emissions from Land-Use Change. Science (80-. ). 319, (2008).

60. Schulze, E.-D., Körner, C., Law, B. E., Haberl, H. \& Luyssaert, S. Large-scale bioenergy from additional harvest of forest biomass is neither sustainable nor greenhouse gas neutral. GCB Bioenergy 4, 611616 (2012).

61. Norman, M. \& Saunders, J. Timber-Sourcing from Fragile and Conflict-Affected States. (2017).

62. COWI. Feasibility study on options to step up EU Action against Deforestation. (2018). doi:10.2779/97793

63. Lambin, E. F. et al. The role of supply-chain initiatives in reducing deforestation. Nat. Clim. Chang. 8, 109-116 (2018).

64. Ashworth, K., Wild, O. \& Hewitt, C. N. Impacts of biofuel cultivation on mortality and crop yields. Nat. 
Clim. Chang. 3, 492-496 (2013).

65. Creutzig, F. et al. Bioenergy and climate change mitigation: an assessment. GCB Bioenergy 7, 916-944 (2015).

66. Xu, J.-Y., Chen, L.-D., Lu, Y.-H. \& Fu, B.-J. Sustainability Evaluation of the Grain for Green Project: From Local People's Responses to Ecological Effectiveness in Wolong Nature Reserve. Environ. Manage. 40, 113-122 (2007).

67. Krause, A. et al. Global consequences of afforestation and bioenergy cultivation on ecosystem service indicators. Biogeosciences 14, 4829-4850 (2017).

68. Purdon, M. Opening the black box of carbon finance "additionality": the political economy of carbon finance effectiveness across Tanzania, Uganda, and Moldova. World Dev. 74, 462-478 (2015).

69. Raftery, A. E., Zimmer, A., Frierson, D. M. W., Startz, R. \& Liu, P. Less than $2{ }^{\circ} \mathrm{C}$ warming by 2100 unlikely. Nat. Clim. Chang. 7, 637-641 (2017).

70. Aldy, J. E. Policy surveillance in the G-20 fossil fuel subsidies agreement: lessons for climate policy. Clim. Change 144, 97-110 (2017).

71. Nordhaus, W. Climate Clubs: Overcoming Free-riding in International Climate Policy. Am. Econ. Rev. 105, 1339-1370 (2015).

72. Steg, L. Limiting climate change requires research on climate action. Nat. Clim. Chang. 8, 759-761 (2018).

73. Brockhaus, M. et al. REDD+, transformational change and the promise of performance-based payments: a qualitative comparative analysis. Clim. Policy 17, 708-730 (2017).

74. Brown, C., Alexander, P., Holzhauer, S. \& Rounsevell, M. D. A. Behavioral models of climate change adaptation and mitigation in land-based sectors. Wiley Interdiscip. Rev. Clim. Chang. 8, e448 (2017). 
75. Noble, I. R. et al. in Climate Change 2014: Impacts, Adaptation, and Vulnerability. Part A: Global and Sectoral Aspects. Contribution of Working Group II to the Fifth Assessment Report of the Intergovernmental Panel of Climate Change (eds. Field, C. B. et al.) 833-868 (Cambridge University Press, 2014).

76. Pindyck, R. S. The Use and Misuse of Models for Climate Policy. Rev. Environ. Econ. Policy 11, 100-114 (2017).

77. Sova, C. A. et al. Multi-level Stakeholder Influence Mapping: Visualizing Power Relations Across Actor Levels in Nepal's Agricultural Climate Change Adaptation Regime. Syst. Pract. Action Res. 28, 383-409 (2015).

78. Azhoni, A., Holman, I. \& Jude, S. Adapting water management to climate change: Institutional involvement, inter-institutional networks and barriers in India. Glob. Environ. Chang. 44, 144-157 (2017).

79. Dovers, S. R. \& Hezri, A. A. Institutions and policy processes: the means to the ends of adaptation. Wiley Interdiscip. Rev. Clim. Chang. 1, 212-231 (2010).

80. Barthel, R. et al. An integrated modelling framework for simulating regional-scale actor responses to global change in the water domain. Environ. Model. Softw. 23, 1095-1121 (2008).

81. Rounsevell, M. D. A. et al. Towards decision-based global land use models for improved understanding of the Earth system. Earth Syst. Dyn. Discuss. 4, 875-925 (2013).

82. Alexander, P., Moran, D., Rounsevell, M. D. A. \& Smith, P. Modelling the perennial energy crop market: the role of spatial diffusion. J. R. Soc. Interface 10, 20130656-20130656 (2013).

83. van Vuuren, D. P. et al. Comparison of top-down and bottom-up estimates of sectoral and regional greenhouse gas emission reduction potentials. Energy Policy 37, 5125-5139 (2009). 
84. Steinbuks, J. \& Hertel, T. W. Confronting the Food-Energy-Environment Trilemma: Global Land Use in the Long Run. Environ. Resour. Econ. 63, 545-570 (2016).

85. Lambin, E. F. \& Meyfroidt, P. Global land use change, economic globalization, and the looming land scarcity. Proc. Natl. Acad. Sci. U. S. A. 108, 3465-72 (2011).

86. Holman, I. P., Brown, C., Janes, V. \& Sandars, D. Can we be certain about future land use change in Europe? A multi-scenario, integrated-assessment analysis. Agric. Syst. 151, 126-135 (2017).

87. Popp, A. et al. Land-use futures in the shared socio-economic pathways. Glob. Environ. Chang. 42, 331-345 (2017).

88. Griscom, B. W. et al. Natural climate solutions. Proc. Natl. Acad. Sci. 114, 11645-11650 (2017).

89. Alexander, P. et al. Assessing uncertainties in land cover projections. Glob. Chang. Biol. 23, 767-781 (2017).

90. Lawrence, D. M. et al. The Land Use Model Intercomparison Project (LUMIP): Rationale and experimental design. Geosci. Model Dev. Discuss. 1-42 (2016). doi:10.5194/gmd-2016-76

91. Zscheischler, J., Rogga, S. \& Busse, M. The Adoption and Implementation of Transdisciplinary Research in the Field of Land-Use Science-A Comparative Case Study. Sustainability 9, 1926 (2017).

92. Turner II, B. et al. Socio-Environmental Systems (SES) Research: what have we learned and how can we use this information in future research programs. Curr. Opin. Environ. Sustain. 19, 160-168 (2016).

93. WTO (World Trade Organisation). Agricultural Risk Management in Brazil. (2016).

94. Delang, C. \& Yuan, Z. China's grain for green program: A review of the lagest ecloogical resotration and rural development program in world. (2015). doi:10.1007/978-3-319-11505-4

95. Forestry Commission Scotland. Woodland Grant Scheme 1 - Datasets. (2017). Available at: 
https://data.gov.uk/dataset/woodland-grant-scheme-1. (Accessed: 26th May 2017)

96. ERS. USDA ERS - Adoption of Genetically Engineered Crops in the U.S. (2017). Available at: https://www.ers.usda.gov/data-products/adoption-of-genetically-engineered-crops-in-the-us.aspx. (Accessed: 23rd January 2018)

97. FSA. Conservation Reserve Program Statistics. (2016). Available at: https://www.fsa.usda.gov/programs-and-services/conservation-programs/reports-andstatistics/conservation-reserve-program-statistics/index. (Accessed: 23rd January 2018)

98. EDINA. Agcenus data for England and Wales. (2012).

99. FAO (Food and Agriculture Organisation of the United Nations). FAOSTAT. (2018). Available at: http://www.fao.org/faostat/en/\#data/QC. (Accessed: 24th August 2018)

100. Data.Gov.UK. Crop areas UK time series - Resources. (2017). Available at: https://data.gov.uk/dataset/june_survey_of_agriculture_and_horticulture_uk/resource/14594f48af59-422a-8230-5dc33405d286. (Accessed: 23rd January 2018) 


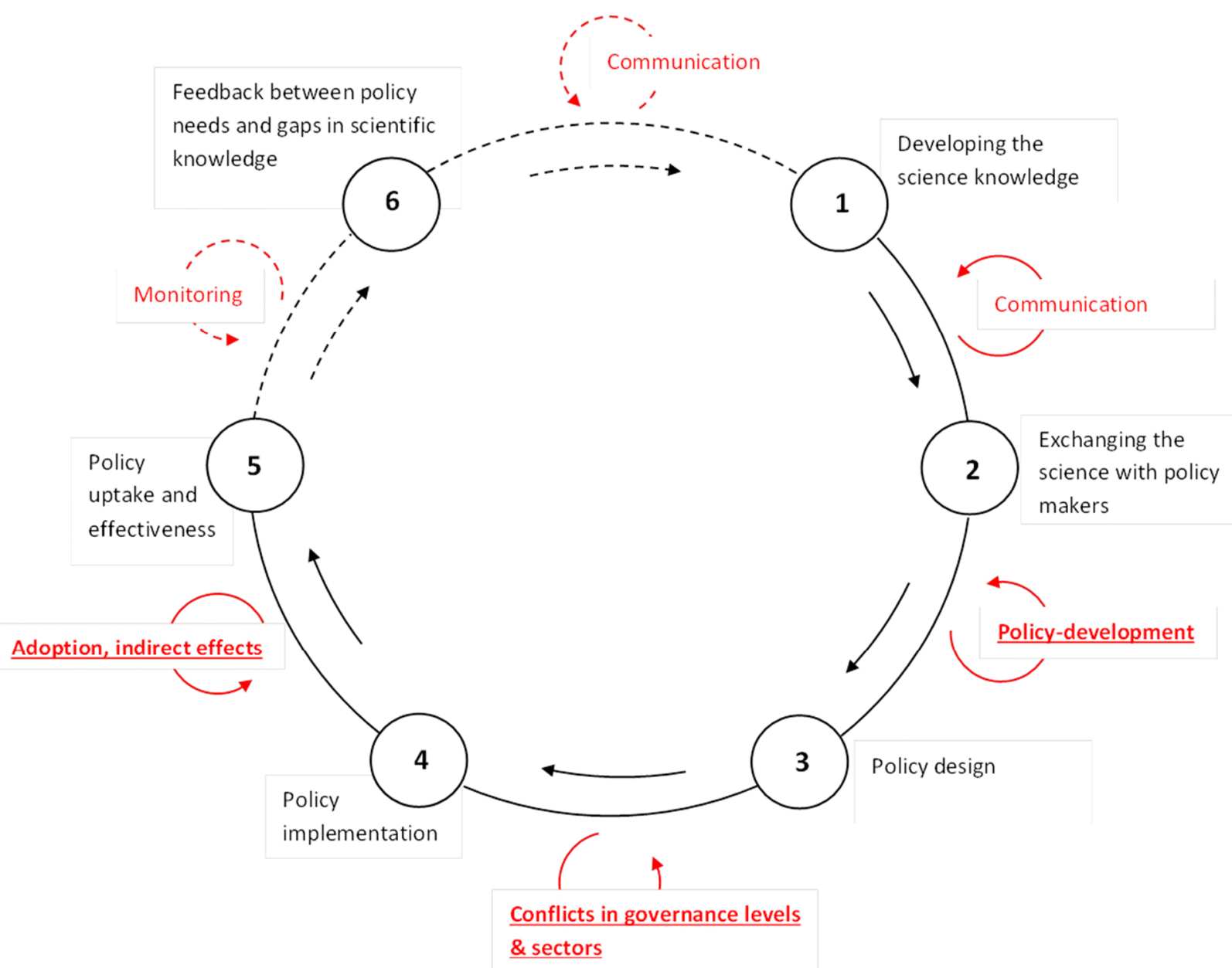

Figure 1. The science-policy exchange cycle and associated time lags: Science-based policy making is a cyclical process that involves potential time lags (red) at each step, which may also reduce policies' ultimate impact. Whilst a cyclical relationship is shown, each lag can occur independently of any other and may prevent further progression. Time lags underlined in bold are those focused on here. Monitoring of policy impacts and feedbacks to new scientific research (dashed lines) are particularly uncertain processes that may not only involve time lags, but may effectively not occur. 


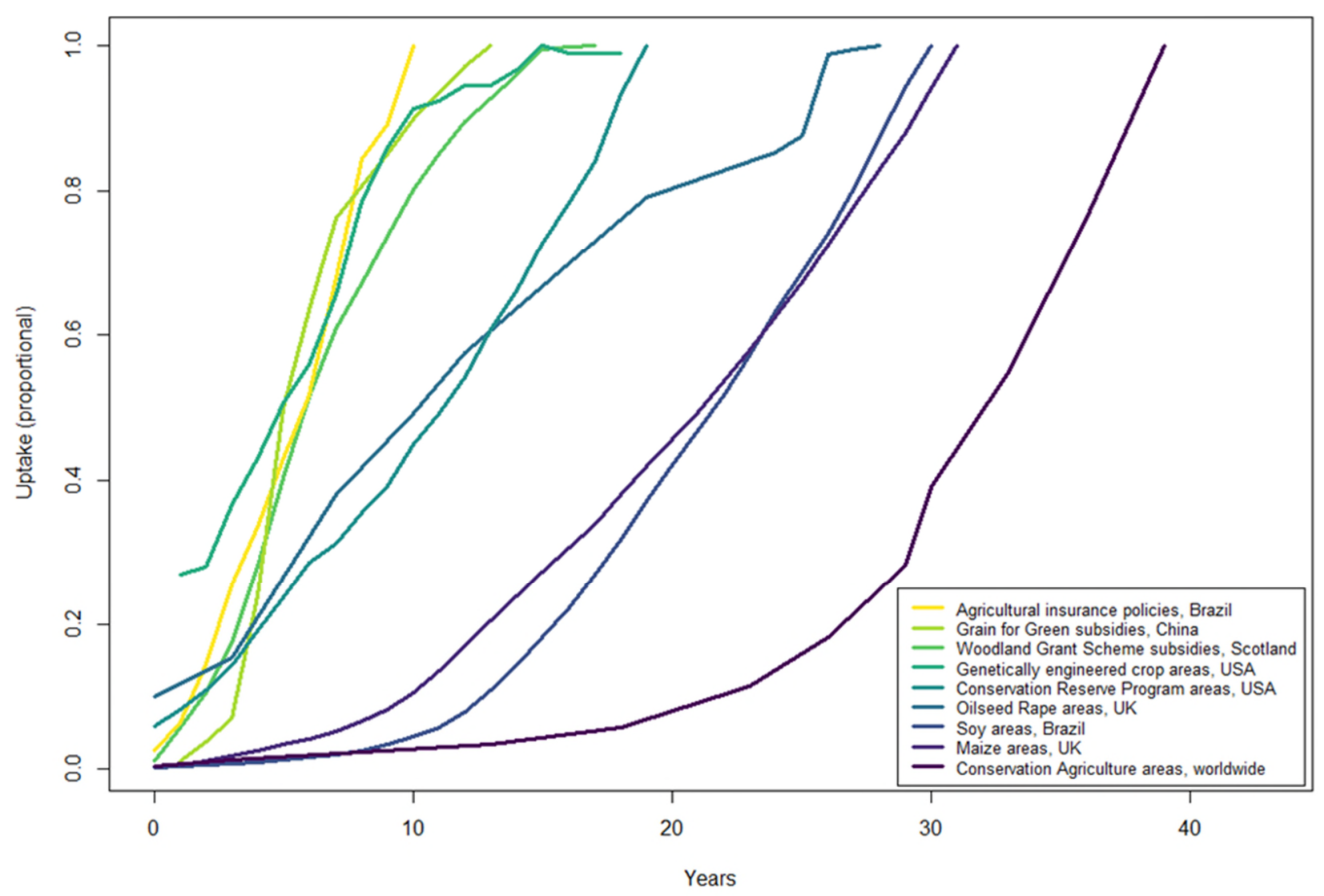

Figure 2. Examples of time lags in uptake of innovations in land use (subsidy schemes, new crops or

management approaches). Individual lines show cumulative uptake of each example, from the year of first data availability (re-based to year ' 0 '; by which point some uptake may have already occurred). An uptake value of ' 1 ' represents the maximum recorded cumulative uptake over the time period, rather than any measure of potential uptake; the plot therefore compares rates rather than extents of uptake, with ongoing increases indicating continuation of uptake processes. Uptake is subject to relatively static conditions in some cases (e.g. subsidy schemes) and influenced by social, economic, technological and political changes in others (e.g. crop areas). Time periods and data sources: Agricultural insurance policies, Brazil (2006-2016) ${ }^{93}$, Grain for Green subsidies, China (1999-2011) ${ }^{94}$, Woodland Grant Scheme subsidies, Scotland (1988-2005) ${ }^{95}$, Genetically engineered crop areas, USA (2000-2017) ${ }^{96}$, Conservation Reserve Program, USA (1986-2015) ${ }^{97}$, Oilseed Rape areas, UK (1969-1997) ${ }^{98}$, Soy areas, Brazil (1961-1991) ${ }^{99}$, Maize area, UK (1984-2014) ${ }^{100,}$ Conservation Agriculture areas, worldwide (1974-2013) ${ }^{56}$. 